NOTE

\title{
Analyses of DNA obtained from shells and brine-preserved meat of the giant clam Tridacna maxima from the central Pacific Ocean
}

\author{
Jonathan P. A. Gardner ${ }^{1, *}$, Carolin Boesche ${ }^{1,2,3}$, Jan M. Meyer ${ }^{1,2}$, Ann R. Wood ${ }^{1}$ \\ ${ }^{1}$ Centre for Marine Environmental and Economic Research, School of Biological Sciences, Victoria University of Wellington, \\ PO Box 600, Wellington 6140, New Zealand \\ ${ }^{2}$ Department of Chemistry and Biology, University of Bremen, 28334 Bremen, Germany \\ ${ }^{3}$ Present address : Carl von Ossietzky University of Oldenburg, 26111 Oldenburg, Germany \\ ${ }^{4}$ Present address: Department of Chemistry and Biology, University of Bremen, 28334 Bremen, Germany
}

\begin{abstract}
DNA was extracted from giant clam Tridacna maxima shells and from brinepreserved meats for sequencing of the cytochrome $c$ oxidase I gene (COI). We examined COI variation in clams from Palmyra Atoll (Line Islands) and Tarawa (Kiribati) and incorporated our data into an existing phylogeographic analysis to identify one new central Pacific Ocean clade of clams. We highlight the utility of the DNA extraction procedures to address questions about illegal harvesting, sources of clams for the aquarium trade, and the origin of museum specimens.
\end{abstract}

KEY WORDS: Giant clams · Tridacna $\cdot$ DNA extraction $\cdot$ Phylogeography $\cdot$ Conservation

\section{INTRODUCTION}

Giant clams (Cardiidae: Tridacninae) are an important component of tropical reef communities. They provide a food source and physical substrate for reef-associated organisms (Alcazar 1986, MingoaLicuanan \& Gomez 2002), live in symbiosis with photosynthetic dinoflagellates and as such are important secondary producers (Klumpp \& Griffiths 1994, Baillie et al. 1998), and may be seen as an indicator of the water quality and health of coral reef environments (Paetzold et al. 1991, Roberts et al. 2002).

Tridacna maxima (Röding, 1798) is the most wideranging species of the giant clam family, being present in reef communities throughout the Indian Ocean, the Red Sea, the Indo-Malay Archipelago, Australia as well as in the central and eastern Pacific (Goh \& Todd 2010). Because they occur in shallow, well-lit water, the clams are vulnerable to being over-harvested for food and collected for the aquarium trade (Gomez \& Mingoa-Licuanan 2006). Giant clams are listed on the International Union for Conservation of Nature (IUCN) Red List of Threatened Species (www.iucn.org) and are now protected by the Convention on International Trade of Endangered Species (www.cites.org - refer to AC22 Doc. 10.2 Annex 8f).

The availability of clam shells (both illegally obtained and, for example, legally held in museum collections) and the availability of clam meat on many tropical markets provides an opportunity and a need to test whether it is possible to obtain DNA of sufficient quality from such material to permit identification of species and area of collection. Such information may be of value to help reduce illegal collecting and trafficking of clams, and it may also be important in helping to better understand the phylogeography of individual species. The most recent analysis of Tri- 
dacna maxima phylogeography has identified 4 genetically related clades based on variation at the cytochrome $c$ oxidase I gene (COI; Nuryanto \& Kochzius 2009). The recognition of such clades provides an important framework for identifying the source region of shells or meat. However, the work of Nuryanto \& Kochzius (2009) did not extend into the central or east Pacific region, meaning that clams from this part of the world cannot yet be placed into known clades.

This study has 2 main aims. First, to determine if it is possible to use clam shells and brine-preserved meat as sources of DNA. Second, to investigate the genetic population structure and phylogeography of the giant clam Tridacna maxima at sites in the central Pacific and to compare the results from those sites to published data for sites elsewhere (Nuryanto \& Kochzius 2009).

\section{MATERIALS AND METHODS}

Samples were collected from 3 locations in the central Pacific: Tarawa Atoll (Republic of Kiribati, $1^{\circ} 22^{\prime} \mathrm{N}, 173^{\circ} 09^{\prime} \mathrm{E}$ ), Palmyra Atoll (USA, $05^{\circ} 52^{\prime} \mathrm{N}$, $162^{\circ} 06^{\prime} \mathrm{W}$ ) and Kingman Reef (USA, $6^{\circ} 24^{\prime} \mathrm{N}$, $162^{\circ} 24^{\prime} \mathrm{W}$ ) (Fig. 1). Tarawa is located $\sim 2000 \mathrm{~km}$ to the west of Palmyra and Kingman.

Shells of Tridacna maxima were collected from Palmyra Atoll $(\mathrm{n}=14$ ind. collected between 2006 and 2010) and Kingman Reef $(n=7$, collected in 2009). Valves were articulated and did not have obvi-

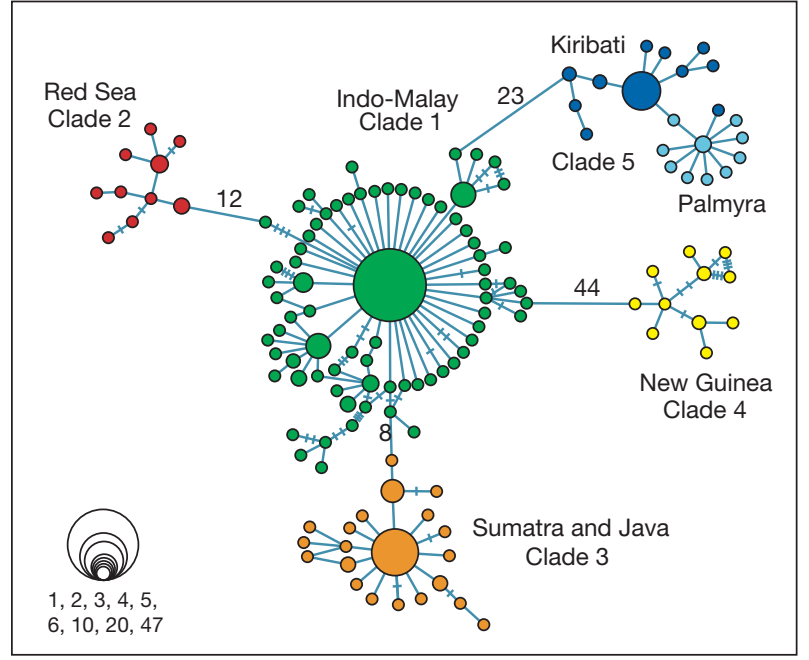

Fig. 2. Tridacna maxima. Network of 140 mitochondrial cytochrome $c$ oxidase I haplotypes from 250 ind. Connection lines represent one mutational step. The hatches and numbers indicate additional mutational steps. The size of the circles represents the haplotype frequency (modified from Nuryanto and Kochzius 2009)

ous evidence of shell degradation such as growth on the inside of the valves by fouling organisms (note that permit constraints prevent collection of soft tissue from these 2 sites). DNA was extracted from airdried hinge ligament material (Doherty et al. 2007) which was cut from the shells under sterile conditions and was ground with dry ice using a sterile pestle and mortar. Genomic DNA was extracted using QIAGEN DNEASY blood and tissue kit (Qiagen) following the manufacturer's protocol, except that the digestion time was increased from $6 \mathrm{~h}$ to $\sim 48 \mathrm{~h}$. Incubation at $56^{\circ} \mathrm{C}$ was carried out in a shaker at $250 \mathrm{rpm}$; a further $20 \mu \mathrm{l}$ of Proteinase $\mathrm{K}$ was added after $24 \mathrm{~h}$. Meat samples of whole $T$. maxima $(\mathrm{n}=$ 25 , collected in 2009) were collected from Tarawa Lagoon, the Republic of Kiribati, and were preserved in brine (saturated salt water solution). This was a collection for food made by a native of Kiribati and not a specifically planned collection for this work, hence no shells were available to us. Small tissue subsamples were removed from these meats and used as source material. Genomic DNA was extracted using QIAGEN DNEASY blood and tissue kit (Qiagen) following the manufacturer's recommenda-
Fig. 1. Tridacna maxima. Map of sample collection locations: KIR - Tarawa Lagoon, Republic of Kiribati; KRF-Kingman Reef, USA; PAL - Palmyra Atoll, USA (modified from http://yachtpals.com). 
tions. A fragment of the mitochondrial COI was amplified using tridacnid-specific primers (Kochzius \& Nuryanto 2008) and was run as a molecular marker against all samples. PCR amplifications were performed in $25 \mu \mathrm{l}$ volumes containing $1 \mu \mathrm{l}$ DNA template, $2.5 \mu \mathrm{l}$ of $10 \mathrm{x}$ Ex Taq Buffer, $2 \mathrm{mM}$ of $\mathrm{MgCl}_{2}$, $10 \mu \mathrm{M}$ of each primer, $250 \mu \mathrm{M}$ of each dNTP, and 1 unit TaKaRa Ex Taq polymerase. The following thermal profile was used: $94^{\circ} \mathrm{C}$ for $3 \mathrm{~min}$, followed by 40 cycles of $1 \mathrm{~min}$ at $94^{\circ} \mathrm{C}, 1.5 \mathrm{~min}$ at $50^{\circ} \mathrm{C}$, and $1 \mathrm{~min}$ at $72^{\circ} \mathrm{C}$. The final extension was carried out for $5 \mathrm{~min}$ at $72^{\circ} \mathrm{C}$. PCR products were purified using a Roche high pure PCR product kit following the manufacturer's protocol. Gels containing DNA from hinge ligament and from meat were run to test for PCR product concentrations and also to ensure comparability of products across all PCR amplifications. Electrophoresis was performed using 1\% agarose (Sigma) in Tris/Borate/ EDTA buffer. Both strands were sequenced using BigDye Terminator chemistry (Applied Biosystems) at the Allan Wilson Centre Genome Service, Massey University, New Zealand.

Sequences were edited using the programme Sequence Navigator (v.1.0.1; Applied Biosystems) and checked by eye. No DNA contamination was observed. In order to check for a functional mitochondrial DNA sequence and to exclude sequencing errors or the amplification of a nuclear pseudogene, the DNA sequences were translated to amino acid sequences with the programme Squint (www.cebl. auckland.ac.nz/index.php). The obtained protein sequence was then compared to COI protein sequences in the NIH database (http://blast.ncbi.nlm.nih. gov/Blast.cgi). An alignment of the sequences was achieved with ClustalW (Thompson et al. 1994) as implemented in the software BioEdit (v.7.0.4.1; Hall 1999). In addition, 117 haplotype sequences used in the data analyses obtained from 211 ind. from the Indo-Malay Archipelago and the Red Sea were downloaded from the EMBL sequence data base (accession number FM244476-FM244485 and FM244513-FM244619; Nuryanto \& Kochzius 2009). Data analysis was based on the inclusion of results from Nuryanto \& Kochzius (2009) in order to expand and compare their findings from the IndoMalay Archipelago and the Red Sea to the Central Pacific.

The programme Arlequin (v. 3.5.1.2; Schneider et al. 2000) was used to calculate haplotype diversity $h$ (Nei 1987) and nucleotide diversity $\pi$ (Nei \& Jin 1989). The significance of the genetic population structure was analysed with pairwise $F_{\mathrm{ST}}$ values and analysis of molecular variance (AMOVA; Excoffier et al. 1992). A haplotype network was also calculated using Arlequin. Clades were defined based on the number of mutational steps between them, following Nuryanto \& Kochzius (2009).

\section{RESULTS AND DISCUSSION}

DNA was successfully extracted from the hinge ligament of 14 different giant clam shells from Palmyra. Overall, this represented a success rate of $\sim 50 \%$. In other attempts, DNA has been successfully extracted from marine mussel (Mytilus spp.) valves dating back to the 1970s (Doherty et al. 2007) and also from freshwater mussel (Margaritifera margaritifera) valves (Geist et al. 2008), although DNA extraction success rates may be low $(\sim 10 \%)$ depending on age of the valves and the environmental conditions that they have experienced. Although we were able to extract DNA from the hinge ligament of shells from Kingman, it was of poor quality and the product could not be amplified via PCR. Attempts were made to optimise the DNA extraction and PCR procedures but these were not successful. We suspect that this location-specific difference arises from the fact that the Palmyra shells were collected from newly dead clams, meaning that ligament tissue had not experienced much degradation, whereas Kingman shells were collected from clams that had been dead for longer periods of time, as judged by the state of shells and ligament condition, and had deteriorated too much (in a qualitative sense the Palmyra shells looked 'cleaner' and therefore more recently dead than the Kingman shells). High quality DNA was extracted from all 25 brine-preserved meat samples collected from Kiribati. This is the first demonstration of the extraction of DNA of sufficient quantity and quality for sequencing from both hinge ligament samples and from brine-preserved meat. Given the widespread availability of both shells and meat, this technique may prove to be particularly useful in tracking and tracing illegal trade in giant clams.

A $413 \mathrm{bp}$ fragment of the COI gene was obtained from 39 Tridacna maxima from Palmyra and Kiribati, yielding 23 haplotypes. Sequences were compared to the 117 haplotypes reported by Nuryanto \& Kochzius (2009). High $h$ was observed within each population, while $\pi$ was less than one percent for all populations except that from Kiribati. Observed $h$ ranged from 0.80 in the populations from Sumatra and Java, to 0.97 in New Guinea; $\pi$ ranged from $0.22 \%$ at Palmyra to $1.44 \%$ at Kiribati (Table 1). Overall $h$ was 0.90 and $\pi$ was $0.69 \%$. 
Table 1. Sample sites, numbers of sequences (n), number of haplotypes (Nhp), haplotype diversity $(h)$, and nucleotide diversity $(\pi)$ based on cytochrome $c$ oxidase I sequences of Tridacna maxima. Clades 1 to 5 inclusive are from Nuryanto \& Kochzius (2009)

\begin{tabular}{|lccccc|}
\hline \multirow{2}{*}{ Code } & Population & $\mathrm{n}$ & \multicolumn{3}{c|}{ Genetic diversity } \\
& & & Nhp & $h$ & $\pi(\%)$ \\
\hline Clade 1 & Central Indo-Malay & 139 & 75 & $0.88 \pm 0.026$ & $0.61 \pm 0.37$ \\
Clade 2 & Red Sea & 13 & 10 & $0.95 \pm 0.051$ & $0.57 \pm 0.37$ \\
Clade 3 & Sumatra and Java & 46 & 21 & $0.80 \pm 0.059$ & $0.32 \pm 0.22$ \\
Clade 4 & New Guinea & 13 & 11 & $0.97 \pm 0.039$ & $0.97 \pm 0.58$ \\
Clade 5 & Central Pacific & 39 & 23 & $0.93 \pm 0.032$ & $1.29 \pm 0.70$ \\
PAL & Palmyra & 14 & 11 & $0.93 \pm 0.061$ & $0.22 \pm 0.18$ \\
KIR & Kiribati & 25 & 12 & $0.84 \pm 0.069$ & $1.44 \pm 0.79$ \\
\hline
\end{tabular}

The hierarchical AMOVA had a high and statistically significant fixation index value $(0.881, \mathrm{p}<0.001)$ which indicates $88.13 \%$ of the variation occurs among the clades. The identification of a new central Pacific clade (Palmyra and Kiribati) is an important addition to the work of Nuryanto \& Kochzius (2009). Analysis of Tridacna maxima samples from locations to the east is still required to provide a full phylogeographic understanding of the genetic structuring of populations of this widely distributed clam.

In conclusion, we suggest that the

The haplotype network revealed 5 distinct clades (clades 1 to 4 are those reported by Nuryanto \& Kochzius 2009) and consisted of 140 haplotypes (Fig. 2). The identification of Clade 5, the central Pacific clade, is new. It is distinguished by 23 mutations from Clade 1, the ancestral Indo-Malay clade. The populations in the Indo-Malay Archipelago show panmixia (Nuryanto \& Kochzius 2009), but cannot be identified from the data provided by the EMBL database in this study and therefore the populations were grouped together according to the clades (Fig. 2).

Analysis revealed highly significant pairwise $F_{\mathrm{ST}}$-values for all groups, ranging from 0.37 to 0.96. These values, and the number of mutational steps between clades (minimum of 8, maximum of 44), suggest little or no genetic connectivity among clades, but do indicate that there is some genetic connectivity among sites within clades (Table 2). For example, clams at Palmyra and Kiribati have some overlap in terms of haplotypes (Clade 5, see Fig. 1).

Table 2. Pairwise $F_{\mathrm{ST}}$-values between populations of Tridacna maxima in the Indo-West and Central Pacific, based on mitochondrial cytochrome $c$ oxidase I sequences. IND Indo Malay Archipelago; RDS - Red Sea; SAJ — Sumatra and Java; NWG - New Guinea; PAL - Palmyra Atoll; KIR - Tarawa Lagoon, Kiribati. All $F_{\mathrm{ST}}$-values statistically significant, $\mathrm{p}<0.001$. Clades IND, RDS, SAJ, and NWG are from Nuryanto \& Kochzius (2009)

\begin{tabular}{|lcccccc|}
\hline & IND & RDS & SAJ & NWG & PAL & KIR \\
\hline IND & - & & & & & \\
RDS & 0.82 & - & & & & \\
SAJ & 0.83 & 0.90 & - & & & \\
NWG & 0.91 & 0.90 & 0.95 & - & & \\
PAL & 0.92 & 0.95 & 0.96 & 0.94 & - & \\
KIR & 0.88 & 0.84 & 0.90 & 0.85 & 0.37 & - \\
\hline
\end{tabular}

ability to extract DNA from hinge ligament and from brine-preserved meat samples may prove to be informative for further studies of giant clams (and indeed other species - e.g. Doherty et al. 2007, Geist et al. 2008). Further testing is required to determine just how much hinge ligament degradation can be tolerated in the DNA extraction and sequencing process, but in principle the process may be applied to examine genetic variation in museum specimens and to confirm region of origin of legally and illegally collected shells. The high-quality DNA obtained from brine-preserved tissue samples that had been destined for human consumption also highlights the potential of this technique in identifying giant clam meat itself (where this is not already obvious) as well as identifying the meat to species level and region of collection (e.g. in the case of illegally collected meats or for live clams in the aquarium trade).

Acknowledgements. Clam shells were collected from Palmyra Atoll and Kingman Reef under authority of a Special Use Permit from the US Fish and Wildlife Service issued to J.P.A.G. We thank A. Meyer (US Fish and Wildlife Service) for her help obtaining specimens from Kingman Reef. Clam meat was collected with permission from Tarawa, Republic of Kiribati by local residents and provided by T. Tamaroa. We thank S. Doherty for helpful discussions about DNA extractions. Thanks to J. Collen for producing both figures. This is contribution no. 0078 from the Palmyra Atoll Research Consortium.

\section{LITERATURE CITED}

Alcazar SN (1986) Observation on predators of giant clams (Bivalvia: Family Tridacnidae). Silliman J 33:1-9

Baillie BK, Monje V, Silvestre V, Sison M, Belda-Baillie CA (1998) Allozyme electrophoresis as a tool for distinguishing different zooxanthellae symbiotic with giant clams. Proc Biol Sci 265:1949-1956

Doherty S, Gosling E, Was A (2007) Bivalve ligament-a new source of DNA for historical studies. Aquat Biol 1: $161-165$ 
Excoffier L, Smouse PE, Quattro JM (1992) Analysis of molecular variance inferred from metric distances among DNA haplotypes: application to human mitochondrial DNA restriction data. Genetics 131:479-491

Geist J, Wunderlich H, Kuehn R (2008) Use of mollusc shells for DNA-based molecular analyses. J Molluscan Stud 74: 337-343

Goh GHS, Todd PA (2010) The distribution and status of giant clams (family Tridacnidae). Raffles Bull Zool 58:103-111

Gomez ED, Mingoa-Licuanan SS (2006) Achievements and lessons learned in restocking giant clams in the Philippines. Fish Res 80:46-52

Hall TA (1999) BioEdit: a user-friendly biological sequence alignment editor and analysis program for Windows 95/98/NT. Nucleic Acids Symposium 41:95-98

Klumpp DW, Griffiths CL (1994) Contribution of phototrophic and heterotrophic nutrition to the metabolic and growth requirements of four species of giant clam (Tridacnidae). Mar Ecol Prog Ser 115:103-115

Kochzius M, Nuryanto A (2008) Strong genetic population structure in the boring clam Tridacna crocea across the Indo-Malay Archipelago: implications related to evolutionary processes and connectivity. Mol Ecol 17: 3775-3787

Editorial responsibility: Matthias Seaman, Oldendorf/Luhe, Germany
Mingoa-Licuanan SS, Gomez ED (2002) Giant clam conservation in Southeast Asia. Trop Coast 9:24-56

Nei M (1987) Molecular evolutionary genetics. Columbia University Press, New York, NY

Nei M, Jin L (1989) Variances of the average numbers of nucleotide substitutions within and between populations. Mol Biol Evol 6:290-300

Nuryanto A, Kochzius M (2009) Highly restricted gene flow and deep evolutionary lineages in the giant clam Tridacna maxima. Coral Reefs 28:607-619

Paetzold J, Heinrichs JP, Wolschendorf K, Wefer G (1991) Correlation of stable oxygen isotope record with light attenuation profiles in reef-dwelling Tridacna shells. Coral Reef 10:65-69

Roberts CM, McClean CJ, Veron JEN, Hawkins JP and others (2002) Marine conservation hotspots and conservation priorities for tropical reefs. Science 295:1280-1284

Schneider S, Roessli D, Excoffier L (2000) Arlequin, version 2.000. University of Geneva, Geneva

Thompson JD, Higgins DG, Gibson TJ (1994) CLUSTAL W: improving the sensitivity of progressive multiple sequence alignments through sequence weighting, position specific gap penalties and weight matrix choice. Nucleic Acids Res 22:4673-4680

Submitted: October 21, 2011; Accepted: January 25, 2012 Proofs received from author(s): April 24, 2012 